\title{
Dodd Frank Act: Reporting CEO Compensation Relationship to Worker Ratio and Firm Performance
}

\author{
Mary Fischer \\ The University of Texas at Tyler \\ Jeffery Lindermoyer \\ Gollob Morgan Peddy PC
}

This study explores the relationship between the firm's CEO cash-based compensation and equity-based (non-cash) compensation and total CEO compensation to firm performance and the pay ratio with the median employee pay as required by the Dodd Frank Act (2010). The analysis uses information for 200 US publicly traded firms with revenues of \$1 billion or more that filed 2018 proxies by April 30, 2019. The study finds a significant relationship of the CEO compensation to the median employee pay and to the pay ratio. The analysis supports past studies that find little, or no, relationship of the CEO compensation with firm financial performance measures including the ROE, ROA, and Tobin $Q$ or the firm's financial measures including total revenue, total assets or leverage. The study does find the Tobin's $Q$ that measures the firm's value is negatively related to the CEO's cash-based compensation. Given these findings, the firms in this study are paying their CEOs greater amounts without regard to the financial performance of the firm.

Keywords: Dodd Frank Act, CEO compensation ratio, median employee pay, firm performance

\section{INTRODUCTION}

Academic literature has consistently touted the issue of Chief Executive Officers (CEO) being overpaid in relation to the rank and file employees. A CEO higher compensation is an expected value as their responsibility and job stress exceed the average worker experience. The ratio between the CEO's compensation and the median employees' compensation has grown by staggering amounts throughout the years. Mishel and Wolfe (2019) report the CEO compensation has grown 940 percent since 1978 whereas the typical worker compensation has risen only 12 percent during the same time period. Davis and Mishel (2014) find the United States CEO-to-worker compensation ratio was 20:1 in 1965 while 2017 data has an average ratio range from 271:1 to 361:1 (Quinnell, 2018) and 2018 data has an average range of 278:1 (Mishel \& Wolfe, 2019).

While many believe CEO salaries and other benefits are too high in comparison to the median employee income, others believe that companies are investing in the leader that can bring higher profitability to the firm. Perel (2003) outlines the conventional belief that CEO compensation is a correlation between the compensation and company performance. However, Sheikholeslami (2001) reports that most of the CEO compensation cannot be linked to any economic benefit experienced by the 
firm. Rather, almost 40 percent of the CEO wages are determined by the size of the firm with larger businesses paying their CEO greater amounts without regard to how the CEO's leadership impacts the financial results of the company (Tosi et al., 2000).

The disparity of CEO compensation to average worker pay comparisons led the US Congress to issue the Dodd-Frank Wall Street Reform and Consumer Protection Act to mandate companies to disclose the CEO compensation to median worker's wage ratio (Dodd-Frank, 2010); Wilmarth, 2011). The ratio disclosure is the driver of this study to find what explains CEO compensation.

This investigation explores (1) what component of the CEO compensation explains or is related to the average workers' pay and (2) what firm performance measure, if any, explains the CEO compensation.

These questions are evaluated using a sample of the 200 top paid US CEOs compensation compiled by Equilar of executive compensation and corporate governance data of public companies in the U.S. with annual revenues of at least $\$ 1$ billion that filed proxies by April 30, 2019 reported in The New York Times (Russel \& Williams, 2019). The reported data are augmented with company performance data obtained from financial statements posted on the company's www page and company information retrieved from Audit Analytics.

The evaluation finds the CEO compensation is positively related to the firm's return on equity but negatively related to return on assets while the CEO's long-term pay and pay leverage negatively impacts the CEO's short-term compensation. Further investigation finds the CEO's total pay does not correlate to the firm's performance such as the return on assets (ROA), the return on equity (ROE) or Tobin's Q. This supports Arraway's (2000) finding that firm performance measures do not explain the total CEO compensation. Contrary to Tosi et al., (2000), this analysis finds firm size i.e., total revenue, total assets and total number of employees has a negative relation to CEO's total compensation.

These results contribute to the literature as prior researchers (Perel, 2003) claim CEO compensation is a corollary of firm's performance which is not supported by this study's findings. It does support (Korobkin \& Dorff, 2018) findings that CEOs compensation is a function of their negotiation skills. These results contribute to the ongoing debate among academics and policy makers about the nature and origins of the widening ratio of CEO compensation to median worker's wages. A discussion of the complexity of the Dodd-Frank Act brings to light the Act's complexity and ramification of certain component of the reporting process.

\section{BACKGROUND}

\section{Dodd-Frank Act and Compensation Reporting}

The Dodd-Frank Act consists of more than 1,500 sections within categories such as financial stability, accountability, investor protections and other provisions (Dodd-Frank, 2010). The Act is very cumbersome with an abundance of categories, but one section is receiving more debate than many of the others - Section 953: executive compensation disclosures.

\section{Executive Compensation Disclosures}

Section 953 consists of two parts: (1) disclosure of pay versus performance, and (2) additional disclosure requirements (Dodd-Frank, 2010). Part 1 requires each publicly traded company to disclose all planned and non-planned compensation for executives, such as, but not limited to the principal executive officer, principal finance officer, and the top three executives. Section 953 Part (1) also requires the disclosure of the relationship between executive compensation actually paid and the entity's financial performance taking into account any change in the value of the shares of stock and dividends and any distribution, which may include a graphic representation of the information required to be disclosed (Dodd-Frank, 2010).

Part 2 provides stockholders with additional security by requiring public companies to disclose (a) the median of the annual total compensation of all employees of the issuer, except the chief executive officer (or any equivalent position) of the issuer; (b) the annual total compensation of the chief executive officer (or any equivalent position), and (c) the ratio of the CEO compensation to the median total wage 
(Dodd-Frank, 2010). The reporting requirement in the Dodd Frank Act that receives much of the criticism and discussion is the median total wage to CEO compensation ratio (Bank \& Georgiev, 2019).

\section{Median Employee Wage Calculation}

The calculation of a publicly traded company's median employee's compensation can be a laborious task. With many employees (part-time and full-time) receiving different types of compensation packages, the calculation creates an enormous compliance task for publicly traded companies. However, the SEC provides an interpretation to assist with the disclosure requirement based on the annual wages paid to employees including an alternative measure based on some other basis if consistently applied (Bloom, 2017). The SEC directs the classification of employees into four categories: full-time, part-time, seasonal, and temporary. Calculating the median employee is not an exact science as it involves estimates, statistical analysis, assumptions, and adjustments. Therefore, the final amount can be a reasonable estimate. Since this is such a strenuous task, this rule allows SEC registered companies to only perform the median employee calculation once every three years, assuming no significant change in the employee population has occurred. Companies can also apply cost-of-living adjustments to their calculations, but it is not necessary (Bloom, 2017). On the other side of the ratio equation, the CEO's salary is less complicated, but it is in no ways a simple task either.

\section{CEO Compensation}

A CEO's salary is not structured as the typical 9am - 5pm employee. Their compensation generally includes a cash portion, stock (or other interest) in the company, a performance factor, as well as other payment methods (Reda, Reifler, \& Stevens, 2014, p.3). Since CEO and other executives' compensation is generally complex, their compensation is determined by a select number of approved board members i.e., the compensation committee, and it is their duty to ensure that each executives' compensation is reasonable and justifiable (Reda, Reifler, \& Stevens, 2014, p.4). The Internal Revenue Code (IRC) Section 1.162.27 (2010) definitions guarantee the independence of the committee members to ensure the executives' compensations are treated as fairly as possible for two reasons: (1) to ensure the pay levels are competitive, because if not, another company may try to recruit the executive and (2) to ensure the compensation levels are neither too high nor too disproportionate, and that there is a reasonable balance between salary, annual bonus, long-term incentives, pension, etc. (Reda, Reifler, \& Stevens, 2014, p.26). However, these compensation committees have been under fire recently to justify their executives' compensation as CEO compensation has grown exponentially over the years (Davis \& Mishel, 2014; Conyon, 2013).

Another responsibility of the compensation committee's action is the pay setting process of the CEO. CEO compensation is a negotiation between a CEO and the committee (Korobkin \& Dorff, 2018). Yao and Appelbaum (2009) find CEO compensation is predicted by CEO aspirations and committee reservations rather than economic indicators with institutional environment having a moderating impact. However, CEOs will try to influence compensation committees to implement performance evaluations when the implementation results in the CEO's compensation to be higher (Jimenez-anguerira \& Stuart, 2015). CEO compensation tends to be a combination of director's self-interest and CEO dominance that renders compensation committee members favorably beholden to overpay their corporation's CEO at the expense of the shareholders (Korobkin \& Dorff, 2018; Strier, 2010; Yao \& Appelbaum, 2009).

\section{This Study}

This study is a response to prior research calls for discussion on chief executive compensation and its relation to firm performance. The investigation explores (1) what component of the CEO compensation explains, or is related to, the average workers' pay and (2) what firm performance measures, if any, explain the CEO compensation.

The remainder of this paper is organized as follows. The next section reviews relevant literature and develops hypotheses for investigation that is then formatted and detailed in a research design section. The research design section describes the data and its sources together with variables used in the analyses. A 
results section presents the findings from the statistical analysis. Finally, a concluding section discusses the findings, their implication, limitations and suggested future research.

\section{LITERATURE REVIEW AND RESEARCH QUESTIONS}

Agency theory has been a component of the economic theory of the firm for almost fifty years (Ross, 1973; Jensen \& Meckling, 1976). Agency theory has also become a theoretical framework for research on CEO compensation (Bratton, 2005). Jensen and Murphy (1990) argue that optimal CEO compensation negotiations can limit agency problems by reconciling manager and shareholder interests. Despite the large number of CEO compensation studies conducted, the results of this stream of research are mixed and inconsistent (Gomes-Mejia \& Wiseman, 1997; Pass, 2003). Pepper and Gore (2015) point out that CEO compensation literature is now extensive as it draws on academic theories such as human capital theory, managerial power hypothesis, institutional theory, political theories and theories about fairness that are found in an array of disciplines including accounting, finance, economics, law, human resource development, and organizational management. They also claim that behavioral agency theory in contrast to Jensen and Mackling's agency theory provides a better framework for theorizing about CEO compensation (Pepper \& Gore, 2015).

Rather than evaluate the effectiveness or efficiency of CEO compensation, this study explores relationships among CEO compensation and firm workforce wages as well as firm performance such as return on assets (ROA), return on equity (ROE) and Tobin's Q.

\section{CEO Compensation and Firm Relationship}

The CEO is typically regarded as the most influential position in the firm. Yet, CEO power can be a two-edged sword: agency theory views CEO power as detrimental to the entity whereas strategic leadership emphasizes the CEO's ability to get things done (Gupta, et al, 2018). That is, the CEO's influence and power may derive from an expectation that the CEO leads the firm in activities that enable the entity to create wealth and maximize future opportunities for shareholders (Van Essen et al., 2012). The influence and power may vary with a CEO's involvement, but they are manifested in the CEO's compensation which is a quantification of the perceived value of the CEO and their negotiation skills (Korobkin \& Dorff, 2018).

Elsayed and Elbardan (2018) report finding evidence for a strong influence of CEO compensation on firm performance based on firm size and leverage which supports the agency theory perspective. This finding contrasts with others who report weak or no association at all (Jensen \& Murphy, 1990; Conyon, 2006; Elsila et al, 2013). Elsayed and Elbardan (2018) find evidence that the use of negotiation by the remuneration committee for determining CEO compensation helps to achieve better firm performance. Attaway (2000) report a weak relationship between CEO compensation and return on equity (ROE). A meta-analysis by Tosi et al. (2000) of firm size, performance and CEO pay reports firm size accounts for more than 40 percent of the variance in CEO compensation where firm performance accounts for less than 5 percent of the variance.

A negative CEO influence that can be harmful to the firm is the CEO's conviction they can do no wrong or make harmful decisions (Park et al., 2018). Malmendier and Tate (2008) point out that CEOs with excessive self-esteem can jeopardize the entity as they have a belief they are acting in the best interest of the shareholders even when the CEO is engages in value-destroying activities. Researchers find CEOs in industries with relatively greater managerial discretion perform worse than other CEOs which suggest that centralized decision making can be a performance concern (Han et al., 2016). Organizations with co-CEOs display an increasing power gap between co-CEO compensation are positively associated with firm performance (Krause et al., 2015). However, this positive performance diminishes when the gaps become excessive.

Based on CEO total compensation, this study studies relationship of the compensation to firm performance using the following variables. Firm size relation to compensation is measured using the log of the firm's net revenue, the log of the number of employees, and log of total assets. Prior research 
indicates past firm performance is a measure of strategic change. The accumulated change relationship to CEO compensation is analyzed using the firm's return on equity (ROE), return on assets (ROA) and Tobin's $Q$, i.e., accounting and market-based firm performance measures, based on Ntim et al. (2015) and Elsayed and Elbardan (2018), as well as the leverage ratio following Sanders (2001) study of CEO stock option pay.

\section{CEO Compensation Constructs}

As indicated in the CEO compensation relation to firm performance, there is a large body of research focusing on the association between CEO compensation and firm performance (Attaway, 2000; Tosi et al., 2000; Elsila et al., 2013; Chengli et al., 2013; Aguinis et al., 2018; Elsayed \& Elbardan, 2018; Ledford \& Lawler, 2018). Given the compensation relationship to firm performance, CEOs should be motivated to enhance and employ security for their own wealth. This investigation investigates total CEO compensation which is the sum of pay components as it relates to the firm's performance. These relationship analyses also require additional research as CEO compensation consists of both short-term and long-term components to determine their relationships with firm value and performance (Henderson \& Fredrickson, 1996; Basuroy et al., 2014). Other researchers (Ntim et al., 2015; Chengli, 2013: GraefeAnderson et al., 2018) argue that CEO compensation is comprised of two sums. The first component is the total cash comprised of base salary, annual bonus, and other monetary out-lays including insurance coverage, cars, housing, travel and other perks. The second component is non-cash items including stocks, deferred benefits, options and other items such as long-term non-monetary incentives. This study includes total CEO pay as well as the cash-based and noncash-based CEO pay in the analyses.

Pay schemes are composed of multiple levels. COE compensation on a short-term or fixed basis keeps the CEO's compensation distant from firm performance (Henderson \& Fredrickson, 1996), while long-term or variable components convince the CEO to act in favor of the firm's goals. Chengli et al., (2013) find short-term pay does not change the relationship between the CEO influence and the firm's performance but positively impacts the firm's return on assets and has a negative impact on market value. However, CEO compensation components including stocks and options, total compensation or pay leverage does impact firm performance by enhancing the firm's return on equity and influences the CEO's overall wealth (Chengli et al., 2013). Other research finds CEO compensation plays an important part in explaining variance in customer satisfaction and firm value (Basuroy et al., 2014). They find CEO short-term compensation i.e., salary, bonus and perks has no impact on customer satisfaction or firm value. However, they report long-term CEO compensation i.e., stock and options interacts negatively with industry concentration but positively with customer satisfaction as well as firm value. Graefe-Anderson et al. (2018) find that CEOs with larger long-term compensation tend to pay their employees lower wages. They also find that the higher long-term compensation contributes to, rather than alleviates, the classic agency conflict.

Based on CEO's compensation, this study studies relationship of the CEO compensation components to firm activities using the following variables. Total CEO compensation, an aggregation off short-term cash pay plus long-term non-cash pay, is measured as a log of the sum of short-term and long-term CEO

pay components. Short-term pay including total salary, bonus and perks relation to firm activities is measured using the log of the cash-based pay. Long-term pay includes stock and option benefit awards relation to firm activities measured using the log of the total non-cash CEO pay. Pay leverage ratio is a calculation of the long-term pay divided by the short-term pay to measure the degree of pay leverage following Chengli et al. (2013) reported findings.

\section{Worker Pay Relationships}

The relationship of top executive and worker compensation has been a research and popular press issue over time from Newman \& Bannister (1998) to Graefe-Anderson et al., (2018). Of concern is the apparent unfairness of CEO compensation that is several multiples of the worker employee pay. Faleye, Reis and Venkateswaran (2013) report the pay differential is primarily determined by the relative bargaining power of workers and CEO to negotiate higher pay when employees are unionized or highly 
skilled. Faleye et al. (2013), also find the CEO-employee pay ratio has no effect on workforce productivity as the employees are protected by unionization or have reason to believe top management is not the primary contributor to the firm performance.

Current CEO pay is at record levels and may impact more than just company operating costs (Benedetti \& Chen, 2018). Their research find workers are less likely to purchase products or want jobs from high CEO-worker pay ratio companies as these firms are less supportive of life balance and compensation based on company size and revenues which supports Mohan et al., (2018) who find that when high pay ratios are disclosed, consumers avoid buying from firms with high CEO to worker ratios. Dittmann et al., (2018) find a correlation of CEO compensation and median worker pay that does not support one another as when CEO compensation increases by 1 percent, the median employee's wage only increases by about 0.04 percent that supports Newman and Bannister's (1998) earlier study.

Given these findings of employee behavior relative to CEO compensation, this study investigates worker earnings and ratio to firm performance to discover what, if any, relations exists. Earlier research findings are used to select analysis measures.

\section{RESEARCH DESIGN}

\section{Data and Sample}

The data for this study is the 200 top paid U.S. CEOs 2018 compensation compiled by Equilar, an executive compensation and corporate governance data firm, of executive compensation and corporate governance data for publicly traded companies in the US with annual revenues of at least $\$ 1$ billion that filed proxies by April 30, 2019 reported in the May 24, 2019 edition of The New York Times (Russel \& Williams, 2019, BU 5). The data reports the median CEO compensation was \$18.6 million an increase of $\$ 1.1$ million or 6.3 percent from the 2017 survey (Eavis, 2019). The CEO pay increased almost twice the rate of worker wages reported at 3.2 percent increase or an extra 84 cents per hours reported by the Bureau of Labor Statistics (BLS, 2019).

Tesla reported the largest pay package to its CEO of $\$ 2.3$ billion that resulted in Equilar revising its reporting chart. Even so, an aggregate survey including all firm sizes reports a median CEO compensation of $277: 1$ for 2018 as compared to $275: 1$ for 2017 (Eavis, 2019). With regards to shareholder value creation, the shareholder return was a negative 5 percent as compared to a plus 20 percent in 2017 and 14 percent in 2016 (Equilar, 2019).

The reported Equilar data (Russel \& Williams, 2019) are augmented with company performance data obtained from financial statements posted on the company's www page and company information retrieved from Audit Analytics.

\section{Variables}

This study centers on CEO compensation which is the total of all pay components. Previous studies (Chengli et al., 2013; Ntim et al., 2018; Elsayed \& Elbardan, 2018) treat CEO compensation as comprised of two separate components. The first component is the cash paid including salary, annual bonus, and other cash payments. The second component is non-cash or equity-based payments including stock, options and other incentive awards. In this study these compensation components are provided by Russel and Williams' (2019) May article in The New York Times. The LOG form of the compensation component values is used to reduce heteroskedasticity.

Evidence about the relationship between firm size and performance are mixed (Ntim et al., 2018). Revenue is the primary corporate performance proxy but as robustness checks, return on equity (ROE), return on assets (ROA) and Tobin's $Q$ as alternative accounting and market-based firm performance measures are employed. Table 1 contains the full definitions of the variables used in this study. 
TABLE 1

SUMMARY OF VARIABLES

\begin{tabular}{|c|c|}
\hline \multicolumn{2}{|c|}{ Compensation variables } \\
\hline СЕОСОМ & natural log of the total $2018 \mathrm{CEO}$ compensation \\
\hline CEOSTPAY & natural log of the sum of 2018 salary, bonus and other annual cash payments \\
\hline CEOLTPAY & $\begin{array}{l}\text { natural log of the sum of } 2018 \text { stock grants, option grants and other long-term } \\
\text { incentive payments }\end{array}$ \\
\hline CEOLEVERAGE & 2018 CEO long-term pay divided by CEO short-term pay \\
\hline \multicolumn{2}{|l|}{ Employee variables } \\
\hline EMPPAY & natural log of 2018 median employee pay provided by Equilar \\
\hline PAYRATIO & ratio of 2018 median employee pay to CEO total compensation \\
\hline STPAYRATIO & ratio of 2018 median employee pay to CEO total annual cash payments \\
\hline LTPAYRATIO & $\begin{array}{l}\text { ratio of } 2018 \text { median employees pay to CEO total long-term incentive } \\
\text { payments }\end{array}$ \\
\hline REVPEREMP & total 2018 corporation revenue divided by number of employees \\
\hline \multicolumn{2}{|c|}{ Firm performance variables } \\
\hline ROA & 2018 return on assets - net income divided by total assets \\
\hline ROE & 2018 return on equity - net income divided by total shareholder's equity \\
\hline Tobin's Q & $\begin{array}{l}\text { Ratio of } 2018 \text { total assets minus book value of equity plus market } \\
\text { capitalization value divided by total assets }\end{array}$ \\
\hline DEBTRATIO & 2018 ratio of total debt to total assets \\
\hline EMPLOYEES & natural log of the total 2018 number of employees \\
\hline LASSETS & natural $\log$ of the total 2018 assets \\
\hline LREVENUE & natural $\log$ of the 2018 firm revenue \\
\hline
\end{tabular}

\section{Data Analysis}

Multiple research questions are analyzed to determine the relations between and among CEO compensation, components of the compensation, other workers at the firm and firm performance.

RQ1: Does firm performance variables explain Total CEO compensation?

RQ2: Does firm performance variables explain short-term (cash) CEO compensation?

RQ3: Does firm performance variables explain long-term (noncash) CEO compensation?

RQ4: Does firm size variables i.e., assets, revenue, number of employees, etc. explain CEO compensation?

RQ5: Does firm performance variables explain the CEO pay ratios to median employee pay?

RQ6: Does firm performance variables explain median employee pay? 
RQ7: Does firm size variables i.e., assets, revenue, number of employees, etc. explain CEO pay ratio to median employee pay?

Statistical analysis is conducted using OLS Regression to answer the research questions. In preparation of the analyses, the compensation of the CEO compensation data was assessed for its statistical values, distribution and normality. As indicated in the ranking report compiled by Russel and Williams (2019), CEO pay ratio for Tesla's chief executive was 40,668:1 as Tesla awarded options totaling \$2.284 billion to CEO Elon Musk whose 2018 annual cash salary was only \$56,380. Using boxplot analyses, the Tesla CEO data was significantly beyond the scale of other CEO compensation data resulting from skewed distribution and extreme standard deviations for CEO compensation, noncash pay, and other relationships. Given these extensive values, the Tesla data was omitted from the analyses as an outlier.

TABLE 2 presents descriptive statistics for the variables used in the analysis.

TABLE 2

DESCRIPTIVE STATISTICS

\begin{tabular}{|l|l|l|l|l}
\hline & $\begin{array}{l}\text { Minimum } \\
\text { Statistic }\end{array}$ & $\begin{array}{l}\text { Maximum } \\
\text { Statistic }\end{array}$ & $\begin{array}{l}\text { Mean } \\
\text { Statistic }\end{array}$ & $\begin{array}{l}\text { Std. } \\
\text { Deviation } \\
\text { Statistic }\end{array}$ \\
\hline CEOCOMP log & 7.1618 & 8.1123 & 7.3185 & 0.1665 \\
\hline CEOSTPAY log & 5.5593 & 7.3620 & 6.7294 & 0.2568 \\
\hline CEOLTPAY log & 6.0000 & 8.0959 & 7.1456 & 0.2430 \\
\hline CEOLEVERAGE & 0.0000 & 344.0479 & 5.6672 & 24.7209 \\
\hline EMPPAY log & 3.7395 & 5.4203 & 4.8366 & 0.3105 \\
\hline PAYRATIO & 61.6324 & 3566.1017 & 450.1091 & 550.7178 \\
\hline STPAYRATIO & 1.6190 & 744.6911 & 118.7068 & 128.5900 \\
\hline LTPAYRATIO & 0.0000 & 3266.5164 & 331.3994 & 465.7338 \\
\hline REVPEREMP & 4.2848 & 7.0595 & 5.7562 & 0.4286 \\
\hline ROA & -0.3903 & 0.3357 & 0.0642 & 0.0775 \\
\hline ROE & -8.3365 & 25.5122 & 0.2360 & 1.9997 \\
\hline TOBIN'S $\boldsymbol{Q}$ & 0.5600 & 13.4152 & 2.3852 & 2.0457 \\
\hline DEBT RATIO & 0.0878 & 1.3191 & 0.6827 & 0.2052 \\
\hline EMPLOYEES log & 2.9345 & 6.3424 & 4.4785 & 0.6015 \\
\hline LASSETS log & 9.2368 & 12.4187 & 10.5260 & 0.6423 \\
\hline LREVENUE log & 9.0355 & 11.7123 & 10.2344 & 0.5504 \\
\hline & & & & \\
\hline
\end{tabular}

The natural logarithm of variables is used to reduce heteroskedasticity. The mean actual CEO cashbased salary is $\$ 1,392$ million while the mean salary of an employee in the study is only $\$ 84.5$ thousand. The mean additional cash component i.e., bonus and perks, of the CEO's compensation is $\$ 6,278$ million while the noncash options, etc. component of the CEO's Compensation is $\$ 16,816$ million. For the indicators of firm performance, ROA with a mean of 0.064 percent, while the Tobin's Q ratio has a mean of 2.385. Additionally, the analysis finds that ROA ranges from -0.390 to 0.336 percent, whereas the 
Tobin's Q ranges from .560 to 13.415 percent. The actual, not log, mean firm net income is $\$ 3,729$ billion with revenues of $\$ 36,548$ billion indicating that most of the firms in the sample are profitable.

The mean of CEO compensation pay ratio in this study is 450:1 as compare to the $277: 1$ ratio reported by Eavis (2019) because this study includes only firms with $\$ 1$ billion in revenue that filed proxies by April 30, 2019. This leads to an assumption that large firms pay a higher CEO compensation.

\section{RESULTS}

\section{CEO Compensation}

Table 3 presents the OLS regression analysis to answer Research Questions 1, 2, 3 and 4 concerning CEO compensation and its cash and noncash components. The variance inflation factor (VIF) for each variable in each analysis tests for the impact of multicollinearity did not exceed 3.5 that is well below Hair et.al. (2010) suggested cutoff value of 5 (p.204).

TABLE 3

OLS REGRESSION OF CEO COMPENSATION

\begin{tabular}{lllllll} 
& \multicolumn{2}{c}{ LOG } & \multicolumn{2}{l}{ LOG } & \multicolumn{2}{l}{ LOG } \\
& \multicolumn{1}{l}{ TOTAL CEO PAY } & \multicolumn{2}{l}{ CEO Cash Pay } & \multicolumn{2}{l}{ CEO NonCash Pay } \\
\hline Intercept & $\mathbf{t}$ & Sig. & t & Sig. & t & Sig. \\
LREVENUE & 4.177 & $\mathbf{0 . 0 0 0}$ & 10.682 & $\mathbf{0 . 0 0 0}$ & 10.850 & $\mathbf{0 . 0 0 0}$ \\
ST CEO PAY & -0.942 & 0.348 & 2.626 & $\mathbf{0 . 0 0 9}$ & 0.267 & 0.790 \\
LT CEO PAY & 13.650 & $\mathbf{0 . 0 0 0}$ & & & 8.387 & $\mathbf{0 . 0 0 0}$ \\
CEOLEVERAGE & 20.045 & $\mathbf{0 . 0 0 0}$ & -4.764 & $\mathbf{0 . 0 0 0}$ & & \\
DEBTRATIO & 8.387 & $\mathbf{0 . 0 0 0}$ & -4.954 & $\mathbf{0 . 0 0 0}$ & 2.100 & $\mathbf{0 . 0 3 7}$ \\
ROE & 1.115 & 0.266 & 0.687 & 0.493 & -0.022 & 0.983 \\
ROA & 1.359 & 0.176 & 1.012 & 0.313 & 1.222 & 0.223 \\
Tobin's Q & -0.818 & 0.415 & 3.409 & $\mathbf{0 . 0 0 1}$ & -0.825 & 0.410 \\
PAYRATIO & -0.483 & 0.630 & -3.207 & $\mathbf{0 . 0 0 2}$ & -0.148 & 0.883 \\
LASSETS & 3.648 & $\mathbf{0 . 0 0 0}$ & 3.917 & $\mathbf{0 . 0 0 0}$ & 9.635 & $\mathbf{0 . 0 0 0}$ \\
REVPEREMP & -0.688 & 0.482 & 0.404 & 0.687 & -1.348 & 0.179 \\
EMPPAY & -1.854 & $\mathbf{0 . 0 6 5}$ & -1.534 & 0.127 & 6.762 & $\mathbf{0 . 0 0 0}$ \\
EMPLOYEES & 3.184 & $\mathbf{0 . 0 0 2}$ & 3.485 & $\mathbf{0 . 0 0 1}$ & -4.744 & $\mathbf{0 . 0 0 0}$ \\
\hline F Value & -1.907 & $\mathbf{0 . 0 5 8}$ & 1.891 & $\mathbf{0 . 0 6 0}$ & -1.161 & 0.247 \\
Adj R & 112.000 & $\mathbf{0 . 0 0 0}$ & 13.748 & $\mathbf{0 . 0 0 0}$ & 17.170 & $\mathbf{0 . 0 0 0}$ \\
Observations & 0.872 & & 0.417 & & 0.476 & \\
\hline & 199 & & 199 & & 199 & \\
\hline
\end{tabular}

From the perspective of RQ 1, only one of the firm performance variables i.e., EMPLOYEES was marginally significant at $p<.10$ in explaining the total CEO compensation. All other firm performance variables i.e., LREVENUE, DEBTRATIO, ROE, ROA, Tobin's Q and LASSETS are found to be insignificant but do contribute significantly to the OSL model that predicts 87.2 percent of the CEO compensation. Ledford and Lawler (2018) suggest that an analysis of the relationship between CEO pay and firm performance should go beyond Tobin's Q and ROA. They contend alternate measures should include what the firm expects of the CEO which is beyond the scope of this study. 
This study finds the CEO compensation is negatively related to the firm's LREVENUE $t=-0.942$ and does not make a major contribution to the CEO compensation model. The more significant variables in the prediction are EMPLOYEES and compensation variables such as CEOLEVERAGE that measures the relationship of the cash and noncash component of the CEO compensation $(p=.000)$, the value of the employee compensation EMPPAY $(\mathrm{p}=.002)$, number of workers in the firm EMPLOYEES $(\mathrm{p}=.058)$, and the revenue divided by the number of workers to determine the revenue per employee REVPEREMP $(\mathrm{p}=.065)$. The RQ 1 conclusion is negative as firm performance does not explain the total value of the CEO compensation. Rather, CEO total compensation is more significantly related to the employee's pay and its relation to the CEO's salary.

RQ 2 regarding whether firm performance explains the CEO cash compensation finds a much different result. Firm performance variables LREVENUE, percent return on assets ROA (an accounting measure), and Tobin's Q (a marketing measure) all contribute significantly to the prediction of the CEO cash pay. However, like the total CEO compensation, the more significant variables in the analysis are EMPLOYEES and compensation variables such as CEO leverage CEOLEVERAGE that measures the relationship of the cash and noncash component of the CEO compensation, the value of the employee compensation EMPPAY, and the number of workers EMPLOYEES in the firm. Although the OLS model is significant, it only explains 41.7 percent of the CEO cash pay. The RQ 2 conclusion also is negative as firm performance does not explain the CEO cash pay. As found in the analysis for RQ1, CEO cash compensation is more significantly related to the employee's pay and its relation to the CEO's cash-based compensation.

The analysis of RQ 3 investigating the explanation of the CEO non-cash pay is comparable to the findings in the analysis of the CEO total compensation. All firm performance variables i.e., LREVENUE, DEBTRATIO, ROE, ROA, Tobin's Q and TASSETS are found to be insignificant but do contribute to the OSL model predicting 47.6 percent of the CEO noncash compensation. The more significant variables in the prediction are EMPLOYEES and compensation variables such as CEOLEVERAGE that measures the relationship of the cash and noncash component of the CEO compensation $(\mathrm{p}=0.037)$, the value of the employee compensation i.e., EMPPAY $(p=.000)$, and the revenue divided by the number of workers to determine the revenue per employee i.e., REVPEREMP $(\mathrm{p} .=.000)$. Thus, the RQ 3 conclusion is negative because firm performance does not explain the CEO noncash pay.

RQ 4 explores whether firm size variables i.e., LASSETS, LREVENUE, the number of EMPLOYEES, etc. explain CEO compensation. Given the data in TABLE 2, the answer to RQ 4 regarding the influence of size in determining CEO compensation, the answer is mixed. The firm's revenue LREVENUE is significant only in the model regarding the CEO cash pay $(p=.009)$, The total assets LASSETS held by the firm are not significant in the model for total CEO compensation, cash pay or noncash pay. The number of employees as a measure of size is weakly significant in determining the CEO total compensation $(\mathrm{p}=.058)$ and CEO cash pay $(\mathrm{p}=.060)$. Thus, size is not overly significant in explaining CEO compensation. However, size is probably not an issue as all the firms in this study are quite large having annual revenue of at least $\$ 1$ billion or more.

\section{Employee and Pay Relationships}

Table 4 presents the regression analysis to answer Research Questions 5, 6 and 7 pertaining to employee pay relations to firm performance, and CEO compensation cash and noncash components. The variance inflation factor (VIF) for each variable in the analysis testing for the impact of multicollinearity is an average of 1.7 that is well below Hair et.al. (2010) suggested cutoff value of 5 (p.204).

RQ 5 investigates whether firm performance explain the pay ratio between the CEO compensation and the median employee pay. The firms in this study are large firms with revenue of at least $\$ 1$ billion and an average pay ratio of the CEO's total compensation of 450:1 (See TABLE 2). The only highly significant firm performance variable was Tobin's Q i.e., an accounting and market-based performance measure $(\mathrm{t}=3.269)$. Although the firms' revenue LREVENUE exceeded $\$ 1$ billion, firm revenue was not 
significant to the CEO compensation to employee pay. Other firm performance measures including ROE, ROA and revenue per employee REVPREEMP were not significant either.

The employee pay EMPPAY relationship to the pay ratio is the more significant and it is negative $(\mathrm{t}=$ -21.104) that means as the CEO compensation increases the median employee pay decreases. This finding was expected based on the 450:1 ratio between CEO and median employee pay. A modest negative relationship found is the number of employees i.e., EMPLOYEES to the pay ratio $(t=-3.230)$. This suggests as the ratio increases the number of employees decreases which begs future research. Both the CEO cash- based and equity-based compensation are significantly related to the CEO to median employee pay ratio. Given that only one of the five firm performance variables in the regression analysis of the CEO to median employee pay ratio was significant in the analysis, the response to RQ 5 is negative as firm performance does not predict the pay ratio.

TABLE 4

OLS REGRESSION OTHER EMPLOYEE AND FIRM PERFORMANCE MEASURES

\begin{tabular}{|c|c|c|c|c|c|c|c|c|}
\hline & \multicolumn{2}{|c|}{ PAYRATIO } & \multicolumn{2}{|c|}{$\begin{array}{l}\text { CASH } \\
\text { CEO } \\
\text { PAYRATIO }\end{array}$} & \multicolumn{2}{|c|}{$\begin{array}{l}\text { NONCASH } \\
\text { CEO } \\
\text { PAYRATIO }\end{array}$} & \multicolumn{2}{|c|}{$\begin{array}{l}\text { MEDIAN } \\
\text { EMPLOYEE } \\
\text { PAY }\end{array}$} \\
\hline & $\mathrm{t}$ & Sig. & $\mathrm{t}$ & Sig. & $\mathrm{t}$ & Sig. & $\mathrm{t}$ & Sig. \\
\hline INTERCEPT & -0.298 & 0.766 & 0.190 & 0.850 & 3.259 & 0.001 & 1.947 & 0.053 \\
\hline LREVENUE & 1.313 & 0.191 & 1.496 & 0.136 & -1.977 & 0.050 & 5.437 & 0.000 \\
\hline ST CEO PAY & 3.926 & 0.000 & & & & & 7.057 & 0.000 \\
\hline LT CEO PAY & 9.691 & 0.000 & 6.223 & 0.000 & & & 3.247 & 0.001 \\
\hline CEOLEVERAGE & 1.774 & 0.078 & -0.520 & 0.604 & 2.933 & 0.004 & 4.631 & 0.000 \\
\hline DEBTRATIO & -1.527 & 0.128 & 0.176 & 0.860 & -1.423 & 0.156 & -1.462 & 0.145 \\
\hline ROE & 1.279 & 0.202 & 0.595 & 0.553 & -0.151 & 0.880 & 1.447 & 0.150 \\
\hline ROA & 0.005 & 0.996 & 2.734 & 0.007 & -1.109 & 0.269 & -0.991 & 0.323 \\
\hline Tobin's Q & 3.269 & 0.001 & -0.231 & 0.818 & 3.113 & 0.002 & 4.307 & 0.000 \\
\hline PAYRATIO & & & & & & & -8.474 & 0.000 \\
\hline EMPLOYEES & -3.230 & 0.001 & 0.665 & 0.507 & 0.080 & 0.936 & -8.305 & 0.000 \\
\hline REVPEREMP & -0.424 & 0.672 & -0.768 & 0.443 & 1.801 & 0.073 & 8.478 & 0.000 \\
\hline EMPPAY & -21.104 & 0.000 & -4.927 & 0.000 & -3.675 & 0.000 & & \\
\hline F Value & 72.723 & 0.000 & 17.607 & 0.000 & 15.933 & 0.000 & 101.959 & 0.000 \\
\hline $\operatorname{Adj} R^{2}$ & 0.785 & & 0.480 & & 0.453 & & 0.850 & \\
\hline Observations & 199 & & 199 & & 199 & & 199 & \\
\hline
\end{tabular}

RQ 6 asks whether firm performance explains the median employee pay. The answer to RQ 6 is a toss-up. Three firm performance measures are significant in predicting the median employee pay i.e., firm revenue LREVENUE ( $\mathrm{t}=5.437)$, revenue per employee REVPEREMP $(\mathrm{t}=8.478)$ and the Tobin's $\mathrm{Q}$ $(\mathrm{t}=4.307)$ that are all positively related to the median employee pay. Overall, the variables in the regression analysis predict 85 percent of the study population based on the median employee pay. Both the cash-based CEO compensation as well as the equity-based CEO compensation and the number of firm employees are significantly related to the median employee pay. Thus, the response to RQ 6 is affirmative. Firm performance variables do go a long way in explaining the median employee pay. 
RQ 7 asks whether firm size variables explains the pay ratio of the CEO compensation to the median employee pay. In a separate regression (not displayed), pay ratio as the independent variable was regressed against the size variables including revenue, net income, total assets, total equity, market capitalization and number of employees. The analysis resulted in an adj $\mathrm{R}^{2}$ of .112 with $\mathrm{F}=5.181$ and significant at .000. The VIF for all variables is 4.0 or less that is an acceptable range. The constant, number of employee and total assets were the only significant variables in the analysis. With the adj $\mathrm{R}^{2}$ of only 11.2 percent, the answer to RQ 7 is a very weak yes.

\section{Addition Analysis}

To examine the robustness of this study's results, several additional analyses (not displayed), use actual values rather than logs in the analyses, alternative firm performance measures debt ratio, and leverage in addition to selected control variable. Although several minor sensitivities occur with regards to some of the coefficients, the results are comparable to those reported in TABLES 3 and 4.

Given Tobin's Q is a strong predictor in this study's OLS analysis, it may be useful to add additional firm performance measures that might result in a stronger observed relationship between the CEO compensation and median employee ratio (Aguinis et al., 2018). Another suggestion is using additional alternative compensation measures such as using the value of the options exercised by the CEO rather than, or in addition to, the value of the options granted as a component of the CEO compensation (Walsh et al., 2018). This addition could alter these finding as equity-based CEO compensation was significant in the models analyzed in this study.

\section{CONCLUSION}

This study investigates the association of the pay ratio of CEO compensation to the median employee pay as it relates to the firm's performance. Consistent with past studies (Aguinis et al., 2018; Ledford \& Lawler, 2018; Tosi et al.,2000), this study finds little, if any, relationship between the CEO compensation ratio to the median employee pay. This study also supports Faleye et al. (2013) findings that CEO pay does not contribute to firm performance. Said another way, CEO compensation and firm performance do not correlate or go hand in hand.

This analysis finds that the CEO compensation and firm performance sensitivity is greater for equitybased compensation than for cash-based compensation that supports prior studies (Jensen \& Murphy, 1990; Conyon, 2006). Evidence of a great association between firm performance and CEO equity-based compensation support the belief that equity-based CEO compensation should form the greater part of the CEO compensation to alien CEO interest with those of the shareholders regardless of the CEO's negotiation skills.

This study suffers from several limitations. First, the sample is limited to those publicly traded firms with revenue in excess of $\$ 1$ billion that filed proxies by April 30, 2019 which limits the ability to generalize regarding CEO pay ratio to the median employee pay in small to medium sized public firms. Smaller firms may well exhibit a much different profile than the larger firm regarding pay ratio, CEO compensation and firm performance. The April reporting also limits how many equity shares CEO will receive under performance-equity award by the end of the fiscal year reporting date when annual performance-equity awards must be reported. Future investigation should include a much more diverse set of public entities to determine what differences exist.

This study has several important contributions for researchers and managers. Incentive compensation is important as corporate compensation committees should not allow the noncash options to reach extreme levels because management's incentives could shift to short-term earnings and away from intangible entity growth. Perhaps future studies might investigate the relationship of the CEO's negotiation capability with the cash and noncash-based components as well as the total CEO compensation. Lastly, if compensation committees are concerned about customer satisfaction, they should consider structuring CEO compensation to a performance format. 


\section{REFERENCES}

Aguinis, H., Gomez-Mejia, L. R., Martin, G. P., \& Joo, H. (2018). CEO pay is indeed decoupled from CEO performance: Charting a path for the future. Management Research: Journal of the Iberoamerican Academy of Management, 16(1), 117-136.

Attaway, M. (2000). A study of the relationship between company performance and CEO compensation. American Business Review, 18(1), 77-85.

Banks, S. A., \& Georgiev, G. S. (2019). Securities disclosure as soundbite: The case of CEO pay ratios. Boston College of Law Review, 60(4), 1125-1203.

Basuroy, S., Gleason, K. C., \& Kannan, Y. H. (2014). CEO compensation, customer satisfaction, and firm value. Review of Accounting \& Finance, 13(4), 326-352.

Benedetti, A. H., \& Chen, S. (2018, November). High CEO-to-worker pay ratios negatively impact consumer and employee perceptions of companies. Journal of Experimental Social Psychology, 79, 378-393.

Bloom, R. (2017). The median employee to CEO pay ratio disclosure requirement. Compensation \& Benefits Review, 49, 34-37.

Bratton, W. (2005). The academic tournament over executive compensation. California Law Review, 93(5), 1557-1584.

Bureau of Labor Statistics (BLS). (2019, January 4). Employment Situation New Release. U.S. Department of Labor: Washington, DC. Retrieved from www.bis.gov/news.resease/archives

Chengli, T., Chen, C., \& Chuang, C. (2013). A study of CEO power, pay structure, and firm performance. Journal of Management \& Organization, 194, 424-453.

Conyon, M. J. (2006, February). Executive compensation and incentives. Academy of Management Perspectives, 20(1), 25-44.

Conyon, M. J. (2013). Executive compensation and board governance in US firms. The Economic Journal, 124(574), F60-F89.

Davis, A., \& Mishel, L. (2014). CEO compensation continues to raise as typical workers are paid less. Economic Policy Institute, 380, 1-12.

Dittmann, I., Schneider, C., \& Zhu, Y. (2018). The real cost of CEO compensation: The effect of behindness aversion of employees. Retrieved from http://hdl.handle.net/1765/109093.

Dodd-Frank Act. (2010). Dodd-Frank Wall Street Reform and Consumer Protection Act. Public Law No. 111-203, § 623, 124 Stat. U.S. Congress: Washington, D.C.

Eavis, P. (2019). It's never been easier to be a CEO and the pay keeps rising. The New York Times. Retrieved from www.nytimes.com/2019/05/24/business

Elsayed, N., \& Elbardan, H. (2018). Investigating the associations between executive compensation and firm performance. Journal of Applied Accounting Research, 19(2), 245-270.

Elsila, A., Kallunki, J., Nilsson, H., \& Sahlstrom, P. (2013, January). CEO personal wealth, equity incentives and firm performance. Corporate Governance: An International Review, 21(1), 26-41.

Equilar. (2019, May 24). New York Times 200 highest paid CEOs. The New York Times. Retrieved from www.equilar.com/reports/64

Faleye, O., Reis, E., \& Venkateswaran, A. (2013). The determinants and effects of CEO-employee pay ratios. Journal of Banking \& Finance, 37, 3258-3272.

Gomez-Mejia, L. R., \& Wiseman, R. M. (1997). Reframing executive compensation: An assessment and outlook. Journal of Management, 23(3), 291-374.

Graefe-Anderson, R., Pyo, U., \& Zhu, B. (2018). Does CEO compensation suppress employee wages? Review of Accounting \& Finance, 17(4), 426-452.

Gupta, V., Han, S., Nanda, V. K., \& Silveri, S. (2018). When crisis knocks, call a powerful CEO (or not): Investigating the contingent link between CEO power and firm performance during industry turmoil. Group \& Organization Management, 43(6), 971-998.

Hair, J. F., Jr., Black, W. C., Babin, B. J., \& Anderson, R. E. (2010). Multivariate Data Analysis. Prentice Hall: Upper Saddle River, NJ. 
Han, S., Nanda, V. K., \& Silveri, S. (2016, Summer). CEO power and firm performance under pressure. Financial Management, 45(2), 369-400.

Henderson, A. D., \& Fredrickson, J. W. (1996, June). Information-processing demands as a determinant of CEO compensation. Academy of Management Journal, 39(3), 575-606.

Internal Revenue Code. (2010). (I.R.C.) §1.162.27 U.S. Congress: Washington, D.C.

Jensen, M., \& Meckling, W. (1976). Theory of the firm: Managerial behavior, agency costs and ownership structure. Journal of Financial Economics, 3, 305-360.

Jensen, M. C., \& Murphy, K. J. (1990). Performance pay and top-management incentives. Journal of Political Economics, 98, 323-329.

Jimenez-anguerira, C. E., \& Stuart, N. V. (2015). Relative performance evaluation, pay-for-luck and double-dipping CEO compensation. Review of Quantitative Finance and Accounting, 44(4), 701732.

Korobkin, R., \& Dorff, M. (2018). Bargaining with the CEO: The case for 'Negotiate first, choose second'. Negotiation Journal, 34(4), 347-377.

Krause, R., Priem, R., \& Love, L. (2015). Who's in charge here? Co-CEOs, power gaps, and firm performance. Strategic Management Journal, 36(13), 2099-2110.

Ledford, G. E. Jr., \& Lawler, E. E., III. (2018). The elusive linkage between CEO pay and performance. Management Research: Journal of the Iberoamerican Academy of Management, 16(1), 57-65.

Malmendier, U., \& Tate, G. (2008). Who makes acquisitions? CEO overconfidence and the market's reaction. Journal of Financial Economics, 89(1), 20-43.

Mishel, L., \& Wolfe, J. (2019, August 14). CEO Compensation has grown 940\% since 1978. Economic Policy Institute.

Mohan, B., Schlager, T., Deshpande, R., \& Norton, M. I. (2018). Consumers avoid buying from firms with higher CEO-to-worker pay ratios. Journal of Consumer Psychology, 28(2), 1033-1050.

Newman, H. A., \& Bannister, J. W. (1998). Cross-sectional differences in corporate compensation structure. Journal of Managerial Issues, 10(2),223-239.

Ntim, C. G., Lindop, S., Osei, K., \& Thomas, D. A. (2015). Executive compensation, corporate governance and corporate performance: A simultaneous equation approach. Managerial and Decision Economics, 36, 67-96.

Ntim, C. G., Park, J., Kim, C., Chang, Y. K., Lee, L., \& Sung, Y. (2018). CEO hubris and firm performance. Journal of Business Ethics, 147, 919-933.

Park, J., Kim, C., Chang, Y. K., Lee, L., \& Sung, Y. (2018). CEO hunbris and firm performance. Journal of Business Ethics, 147, 919-933.

Pass, C. (2003). Long-term incentive schemes, executive remuneration and corporate performance. Corporate Governance, 3, 18-27.

Pepper, A., \& Gore, J. (2015). Behavioral agency theory: New foundation for theorizing about executive compensation. Journal of Management, 41(4), 1045-1068.

Perel. M. (2003). An ethical perspective on CEO compensation. Journal of Business Ethics, 48(4), 381391.

Quinnell, K. (2018, May 22). Executive paywatch 2018: The GAP between CEO and worker compensation continues to grow. Executive Paywatch 2018. Retrieved from www.aflcio.org.

Reda, J. F., Reifler, S., \& Stevens, M. L. (2014). The compensation committee handbook. Somerset, NJ: Wiley

Ross, S. (1973). The economic theory of agency: The principal's problem. American Economic Review, 63, 134-139.

Russel, K., \& Williams, J. (2019, May 24). The highest-paid CEO of 2018: A year so lucrative, we had to redraw our chart. The New York Times, BU 4 - 7.

Sanders, W. G. (2001). Behavior responses to CEOs to stock ownership and stock option pay. Academy of Management Journal, 44(3), 477-492.

Sheikholeslami, M. (2001). EVA, MVA and CEO compensation. American Business Review, 19(1), 1317. 
Strier, F. (2010, July). Runaway CEO pay? Blame the boards. Journal of Corporate Governance, 9(3), 727.

Tosi, H. L., Werner, S., Katz, J. P., \& Gomez-Mejia, L. R. (2000). How much does performance matter? A meta-analysis of CEO pay studies. Journal of Management, 26(2), 301-339.

Van Essen, M., Otten, J., \& Carberry, E. J. (2012, January). Assessing managerial power theory: A metaanalysis approach to understanding the determinants of CEO compensation. Journal of Management, 41(1), 164-202.

Walsh, J. P., White, B. J., \& Edwards, J. R. (2018). The rocky road from insight to understanding. Management Research: Journal of the Iberoamerican Academy of Management, 16(1), 75-79.

Wilmarth, A. E., Jr. (2011). The Dodd-Frank Act's expansion of state authority to protect consumers of financial services. Journal of corporation Law, 36(4), 893-954.

Yao, Y., \& Appelbaum, S. (2009). CEO compensation as a process and a product of negotiation. Corporate Governance, 9(3), 298-312. 